\title{
Revivalist Movements and Religious Contracultures in Finland
}

\author{
By JUHA PENTIKÄINEN
}

\section{Social breakthrough and change in world view}

'The Finnish way of life', 'Finnish culture' and 'Finnish popular life' are concepts which have become firmly established in everyday language. Parallel to them a tendency to speak of "a portrait of Finnish religious life", or a "Finnish world view" has increasingly been in evidence. The religious behavior of the Finns has usually been characterised as an extremely static phenomenon which is further colored by a strong ecclesiastical tradition. This may be seen in that over $92 \%$ of the Finnish population belongs to the Evangelical-Lutheran Church and that the largest religious movements function within this church. ${ }^{1}$ This conception seems to receive additional support by the fact that, with the exception of the most recent neo-pietism (uuspietismi) organised during the period of the second world war, the main revivalist movements functioning within the church are more than a century old: Knee-praying (rukoilevaisuus) from the 18th century, Revivalism (herännäisyys) from the transitional period between the 18th and 19th century, Lestadianism (lestadiolaisuus) and Evangialism (evankelisuus) from the middle of the 19 th century.

It is clear that the hypotheses concerning a 'Finnish way of life', a 'popular culture', 'Finnish religious life' or a 'Finnish world view' all presuppose detailed, multidisciplinary investigation at this moment. Finnish religious movements have been the object of comparatively little research. From the standpoint of sociology. Nevertheless, it is possible to demonstrate the point of emphasis up until this time to have been on structural clarifica-

${ }^{1}$ Cf. Haavio 1965, $20 \mathrm{f}$; Juva, 185 ff; Sihvo, 2 f. 
Aspects of religio-sociological analysis ${ }^{2}$

\begin{tabular}{|c|c|c|c|}
\hline & Structure & Institutions & $\begin{array}{l}\text { Symbolic } \\
\text { environment }\end{array}$ \\
\hline \multirow[t]{2}{*}{ Society } & $\begin{array}{l}\text { 1. Structural view- } \\
\text { point: }\end{array}$ & $\begin{array}{l}\text { 2. Institutional view- } \\
\text { point: }\end{array}$ & $\begin{array}{l}\text { 3. Cultural view- } \\
\text { point: }\end{array}$ \\
\hline & $\begin{array}{l}\text { How has social struc- } \\
\text { ture influenced the } \\
\text { origin, development, } \\
\text { and form of religion? }\end{array}$ & $\begin{array}{l}\text { In what manner does re- } \\
\text { ligion influence the con- } \\
\text { dition, development and } \\
\text { social institutions of a so- } \\
\text { ciety? }\end{array}$ & $\begin{array}{l}\text { What is the relation- } \\
\text { ship between reli- } \\
\text { gion and the prevail- } \\
\text { ing culture of the so- } \\
\text { ciety as a whole? }\end{array}$ \\
\hline Organisation & $\begin{array}{l}\text { 4. What is the social } \\
\text { composition of a re- } \\
\text { ligious community } \\
\text { and how are changes } \\
\text { in it reflected in the } \\
\text { activity of the com- } \\
\text { munity? }\end{array}$ & $\begin{array}{l}\text { 5. What are the rules and } \\
\text { means of coercion pre- } \\
\text { vailing within a religious } \\
\text { society and what is the } \\
\text { nature of their influ- } \\
\text { ence on religious and } \\
\text { secular behaviour within } \\
\text { the society? }\end{array}$ & $\begin{array}{l}\text { 6. What concept of } \\
\text { the secular and spir- } \\
\text { itual world is held by } \\
\text { the members of a re- } \\
\text { ligious community, } \\
\text { in what manner do } \\
\text { these concepts influen } \\
\text { the community? }\end{array}$ \\
\hline Individual & $\begin{array}{l}\text { 7. What structural } \\
\text { features in a society } \\
\text { exert an influence } \\
\text { on the religious be- } \\
\text { havior and attitudes } \\
\text { of an individual? }\end{array}$ & $\begin{array}{l}\text { 8. To what degree are } \\
\text { people bound by religious } \\
\text { customs, rituals and } \\
\text { concepts, and what is the } \\
\text { nature of the manner in } \\
\text { which these exert an in- } \\
\text { fluence on their secular } \\
\text { behavior in different } \\
\text { situations? }\end{array}$ & $\begin{array}{l}\text { 9. How are religious } \\
\text { concepts formed by } \\
\text { individuals and in } \\
\text { what manner do these } \\
\text { influence their man- } \\
\text { ner of conceptualis- } \\
\text { ing the world? }\end{array}$ \\
\hline
\end{tabular}

tions: How has social structure influenced the origin, development, and form of religion? What is the social composition of a religious community and how are changes in it reflected in the activity of the community? What structural features in a society exert an influence on the religious behavior and attitudes of an individual? Considerably less religio-sociological investigation has been carried out from an institutional standpoint: In what manner does religion influence the condition, development, and social in-

\footnotetext{
2 Allardt, 14.
} 
stitutions of a society? What are the rules and means of coercion prevailing within a religious society and what is the nature of their influence on religious and secular behavior within the society? To what degree are people bound by religious customs, rituals, and concepts, and what is the nature of the manner in which these exert an influence on their secular behavior in different situations? The question of the relationship of religion to culture has received almost no attention: What is the relationship between religion and the prevailing culture of the society as a whole? What concept of the secular and spiritual worlds is held by the members of a religious community, in what manner do these concepts influence the community? How are religious concepts formed by individuals and in what manner do these influence their manner of conceptualising the world?

A survey of the Finnish investigatory tradition of sociology of religion demonstrates that emphasis should be concentrated on those areas which, up until now, have been the objects or relative neglect. Religion and religiosity in Finnish society should be studied holistically as a part of the total culture and its structures. It is clear that the commonly used parameters appearing in structural studies of religion, e.g. church membership, attendance at church or communion, provide a very pale picture of a nation's religious behavior. ${ }^{3}$ In the synchronic investigation of religiosity both the ecclesiastical sector of life and all other religious attitudes and activities as evidenced in such spheres as the rules of human behavior, ethics, and morals ought to be the object of detailed investigation. ${ }^{4}$

The social breakthrough of Finnish society and the concomitant change in world view both offer a diachronically interesting area for research. It is a known fact that Finnish society underwent a substantial degree of industrialisation from the second half of the 19th century onward. Industrialisation is thought to have decisively influenced many social phenomena. It is regarded to additionally have played a role as a background factor in mass movements. From the standpoint of church history it is interesting that the Finnish revivalist movements originated before the breakthrough of industrialisation. Nevertheless they were regulated to a decisive degree by pre-industrial social changes, as is pointed out by Kirsti Suolinna in her article "Suomen herätysliikkeet sosiaalisina liikkeinä" (The Finnish revival-

\footnotetext{
${ }^{3}$ Cf. Kortekangas, $1 \mathrm{ff}$.

${ }^{4}$ This has been studied by Koskelainen, 1968, $110 \mathrm{ff}$, and Seppänen, $112 \mathrm{ff}$.
} 
ist movements as a social movement) $)^{5}$. Additionally, internal changes appear to have taken place within religious movements which coincide with the breakthrough of industrialisation.

There are many social changes linked with industrialisation and they exert a decisive influence on cultural and religious breakthrough. From the standpoint of religion, industrialisation and urbanisation have contributed to secularisation and produced a multivalued world view to replace an extremely unified one. ${ }^{6}$ From the standpoint of culture it can be noted that the way of life typical of the countryside has receded with a corresponding increase in the availability of international innovations and the rise of subcultures and coteries. Much of the development in Finland has been regulated by factors such as the internal migration which has taken place during the period of industrialisation and created new situations for cultural contact. Here it would be important to clarify the relationship holding between the different factors responsible for cultural identity and their dependence on overall cultural change.

\section{The background and goals of a multi-disciplinary investigatory project}

In Finland the investigation of religious movements has rather well established traditions, particularly within the theological sciences. Church history has played a special role in producing a long series of monographs dealing with revivalist movements and the religious leaders active within them. Evangialism has been the object of most church-historical investigation up until this time. ${ }^{7}$ There exists a history of Lestadianism in Sweden and Norway ${ }^{8}$ but a total mapping of Finland in this respect has not yet been drawn

\footnotetext{
5 Kirsti Suolinna writes: "The Finnish revivalist movements had become established before the breakthrough of industrialisation. Nevertheless, factors may be found in Finnish society which would explain religious activity. An important pre-industrial social change resulted from the great increase in population which had already begun when Finland was a part of Sweden and which continued vigorously throughout the 19th century. The increase in population primarily benefited that segment of the population which owned no farmstead." She considers the concept suggested by Lipset and Rokkan, 'national revolution' as an appropriate description of the changes that took place. Cf. Suolinna, Kirsti $1969 b, 63$.

${ }^{6} \mathrm{Cf}$. Seppänen, $115 \mathrm{ff}, 137$.

${ }^{7}$ The history of the Evangelical movement has been studied by Arkkila, $1 \mathrm{ff}$, Koskenniemi, $1 \mathrm{ff}$; and Takala, $1 \mathrm{ff}$.

${ }^{8}$ Researchers concerned with this topic have been among others Boreman, 1 ff; Brännström, $1 \mathrm{ff}$; and Sivertsen, Dagmar, $1 \mathrm{ff}$.
} 
up. The Knee-praying movement of south west Finland as well as the Revivalism of Savo and Ostrobotnia have been the subject of several publications, ${ }^{9}$ but the phases of these movements have not been clarified from the perspective offered by modern historical methodology. A history of Neopietism is in the planning stage. In addition to studies carried out from the standpoint of church history there have been studies of the dogmas of the revivalist movements, particularly of the Knee-prayers, ${ }^{10}$ from the standpoint of systematic theology. The meeting institution of the movements has also received some attention within practical theology. In general, the emphasis of the theological research on Finnish revivalist movements has clearly been on investigating religious leaders. There are several studies available dealing with the religious views, doctrinal standpoints, and spiritual development of such figures as Paavo Ruotsalainen, leader of the revivalist movement, Lars Levi Laestadius, founder of Lestadianism, and Juhani Raattamaa, his layman follower, Abraham Achrenius and Henrik Renqvist, main leaders of the Knee-prayers. ${ }^{11}$ Nevertheless the viewpoint of the people, crucial from the aspect of the dynamics of the movement as its supporters, has been neglected.

We see that the history of Finnish revivalism in the 19th century has been the object of thorough investigation; the 20th century has not awakened as much interest as things stand now. The geographical spread of religious movements has been studied in Finland since the 1950 's. ${ }^{12}$ In the 1960 's the interest of sociologists of religion began more and more to be directed towards the Finnish revivalist movements. The first doctoral dissertation dealing with sociology of these movements was that of Ari Haavio: "Evankelinen liike herätysliikkeenä" (The Evangialist Movement as a Revivalist Movement) (1963). Sociological studies of revivalist movements have emphasised structural questions. Objects of special attention have been the

\footnotetext{
${ }^{9}$ Cf. Kares, 1 ff; Rosendal, 1 ff; and Tiililä 1966, 1 ff.

${ }^{10} \mathrm{Cf}$. Tiililä 1961, $1 \mathrm{ff}$; and 1964, $1 \mathrm{ff}$.

$"$ On the history of personalities connected with revivalism: cf. Nyman, 1 ff; Tarvainen 1944, 1 ff; and 1967, 1 ff, as well as Tiililä 1944, 1 ff. Laestadius and Raattamaa have been the topic of publications by Castrén, $1 \mathrm{ff}$; and Zidbäck 1937, $1 \mathrm{ff}$; and 1941, $1 \mathrm{ff}$.

The views of F. Hedberg, founder of the Evangelical movement, and of his disciples have been treated by Schmidt 1948, 1 ff; and Tiililä 1947, 1 ff. Researchers publishing studies of Kneepraying in South-western Finland have been Ruuth, $1 \mathrm{ff}$; and Salonen, $1 \mathrm{ff}$.

${ }_{12}$ The spread of religious movements have been studied by Schmidt 1952, I ff, 1956, Iff; Haavio 1965, I ff; Koskenniemi, 1 ff; Sihvo, 1 ff; Pentikäinen 1975, 77 ff.
} 
influence of social structure on religion, the problem of alienation, and the typology and organisations of the revivalist movement. The religious sociology of Lestadianism has been treated by Kirsti Suolinna who used the Tornio River Valley as the object of her investigation. ${ }^{13}$ In 1971 Heikki Huhtala's semantic-historical investigation "On the Lexical Usage of Finnish Early Pietism and the Knee-prayers" was completed. As pointed out by Kirsti Suolinna in 1969, sociological distinction of the Finnish revivalist movements has up until now been carried out on too small a scale. ${ }^{14}$

The initiation of the interdisciplinary investigatory project dealing with Finnish religious traditions and groupings in 1968 was the result of the then prevailing widely felt interest in different fields towards Finnish religious life. Church history had made new requirements for investigation known: in addition to studies dealing with leaders there was a desire felt for clarification of the position of the revivalist movements as a component of Finnish folk culture. Within the sociology of Religion there was an interest felt in studying religious life in its relationship to social change. Comparative study of religion, the first Finnish beachheads of which was established in Turku in the early 1960's, began to demonstrate interest in the series of problems connected with encounter between religious movements, from the point of view of environment, culture and society. When Mikko Juva and Kauko Pirinen, professors of church history at Helsinki University submitted applications for research funds to the State Council on the Humanities they justified the importance of their program by demonstrating the "unique characteristic" the revivalist movements have in Finnish society from the standpoint of the history and sociology of religion: "The symbiosis between the church and the revivalist movements can be regarded as a typically Finnish institution having no exact equivalent anywhere else." As examples of the types of questions answers to which were sought in the investigation mention might be made of the meeting institution, the spread of the revivalist movements as to commune and village, the mutual relationships between movements, their relationship to church and society, and the social status accorded by the revivalist movements. Because the possibilities of an ind ividual researcher to carry out the task were seen as limited, a committee was proposed having as its members specialists in folklore, church

\footnotetext{
${ }^{13}$ Cf. Suolinna, Kirsti $1969 a, 1 \mathrm{ff}$, and 1971, $89 \mathrm{ff}$.

${ }^{14} \mathrm{Cf}$. id. $1969 b, 62$.

7-752446 H. Biezais
} 
history, psychology of religion, sociology of religion and comparative religion. An interdisciplinary group took care of the planning and methodological programming of the investigation right from the beginning. Its members have been Ari Haavio (sociology), Lauri Honko (comparative religion), Mikko Juva (church history: chairman from 1968 to 1970), Heikki Kirkinen (history), Pentti Laaksonen church history, Eino Murtorinne (church history), Juha Pentikäinen (comparative religion: chairman from 1973 onwards), Kauko Pirinen (church history: chairman from 1971 to 1972). ${ }^{15}$

From its very inception the investigatory committee regarded that the parallel interdisciplinary investigation proposed as a basis for the formulation of questions of a new type both the acquisition of new data collected from the field as well as thorough analysis of the material then available both in archives and in previous studies on an interdisciplinary basis. One of the first tasks was to draw up questionnaires, which would be valid on a nationwide collection dealing with both Lutheran and Orthodox traditions as well as with the collection of information concerned especially with revivalist movements. In order to clarify the interdisciplinary problems in question research seminars were needed in which problems dealing with fieldwork, evaluation of sources, methods of investigation, and selection of analytic techniques were discussed. Simultaneously, training of researchers was initiated encompassing not only doctoral and licentiate candidates, but also students writing master's theses. These had collected material dealing with the church and religious traditions both as individuals and as members of teams primarily from areas in which contact between different revivalist groups had been particularly dynamic. In 1968 the area of primary attention was central Ostrobotnia, an area known as a point of contact between Revivalism, Lestadianism, and Evangialism; in 1969 it was southern Ostrobotnia, known for its Revivalism and Evangialism; in 1971 the bearers of the Greek Orthodox religion who had moved to eastern Finland from the Russian Karelian commune of Salmi; 1972 the Orthodox immigrants from Suojärvi living in northern Savo, etc. The preliminary research dealing with each commune was brought to a culmination in having a student make use of all material available in addition to that he had collected during the course of his field work in doing his master's thesis which was an analysis of one

${ }^{15}$ Cf. Ojaluoto, Elli, $1 \mathrm{ff}$. 


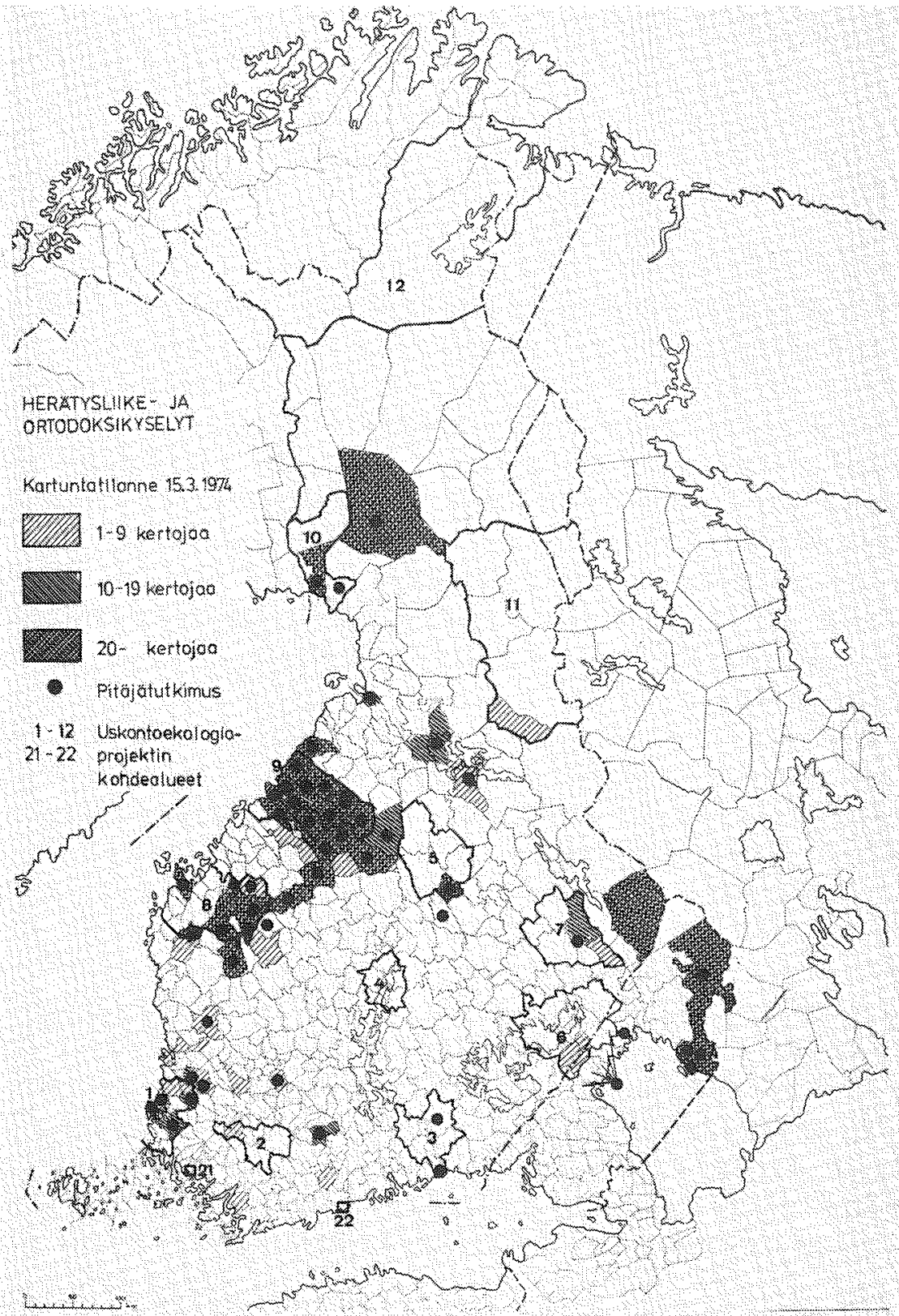

Map 1. Survey of the different Revivalist movements and adherents of the Greek Orthodox church. Situation on March 15, 1974. The upper sign indicates 1-9 respondents; the middle one 10-19 respondents; the lower 20 or more respondents. MA thesis treating one commune, 1-12, 21-22. Target areas of the religio-ecology project. (Uskonnollinen liike, 90.) 
commune. Theses of this type completed within the project now amount to $60(\operatorname{map} 1) .^{16}$

In investigating the material available in archives both normal church archives and the private collections and collections in the possession in the separate movements have been utilised. The reciprocal relationship of social, cultural and religious change in Finland is clarified by the church historical material which has been collected by the priests from 1900 onwards for the church meetings held every fifth year as the culmination of the Evangelical-Lutheran Church administration. One of the main tasks of the investigatory project of Finnish religious movements has been set as the analysis of this diachronic material as a part of the ecology of the Finnish religious movements and their mapping as a contribution to Finnish religiogeography. The statistics and other information gathered by the priests concerning their own congregation used for the church meetings held every five years as well as their projections concerning the social, ethic, and religious development of their congregations provide an abundant amount of illuminative material useful for the clarification of the changes undergone in the Finnish world view during the twentieth century.

The possibility of using the material for comparison in statistical and similar studies is diminished by the fact that the question blanks used in drawing up the annual surveys have undergone a certain degree of change during the course of the years. There is hardly reason to doubt the authenticity of the statistics. On the other hand, the information based upon the views of individual priests might very well be based on factors such as the individual's familiarity with the region and his religious identity. For example, is the priest in question a member of some religious group or does he oppose one? Factors such as the influence of Christian societies on the life of the congregation (in the estimate of the parish priest), the presence of divergent protestant sects or their members within the area, the estimate of the parish priest as to the effect of spread of the revivalist movements, all contribute to the non-commensurability of much of the material. ${ }^{17}$ What the opinion of the common people and its view of the matters to be investigated

\footnotetext{
${ }^{16}$ A list of master's theses has been published in the work "Uskonnollinen liike" (The religious movement), edited by Pentikäinen, 1975.

17 These examples are from the list of parameters for establishing a cross-section used in the religio-ecologic and geographical mapping carried out in 1961. There are 107 variables concerning the entire country included in the list and 335 concerning target areas.
} 


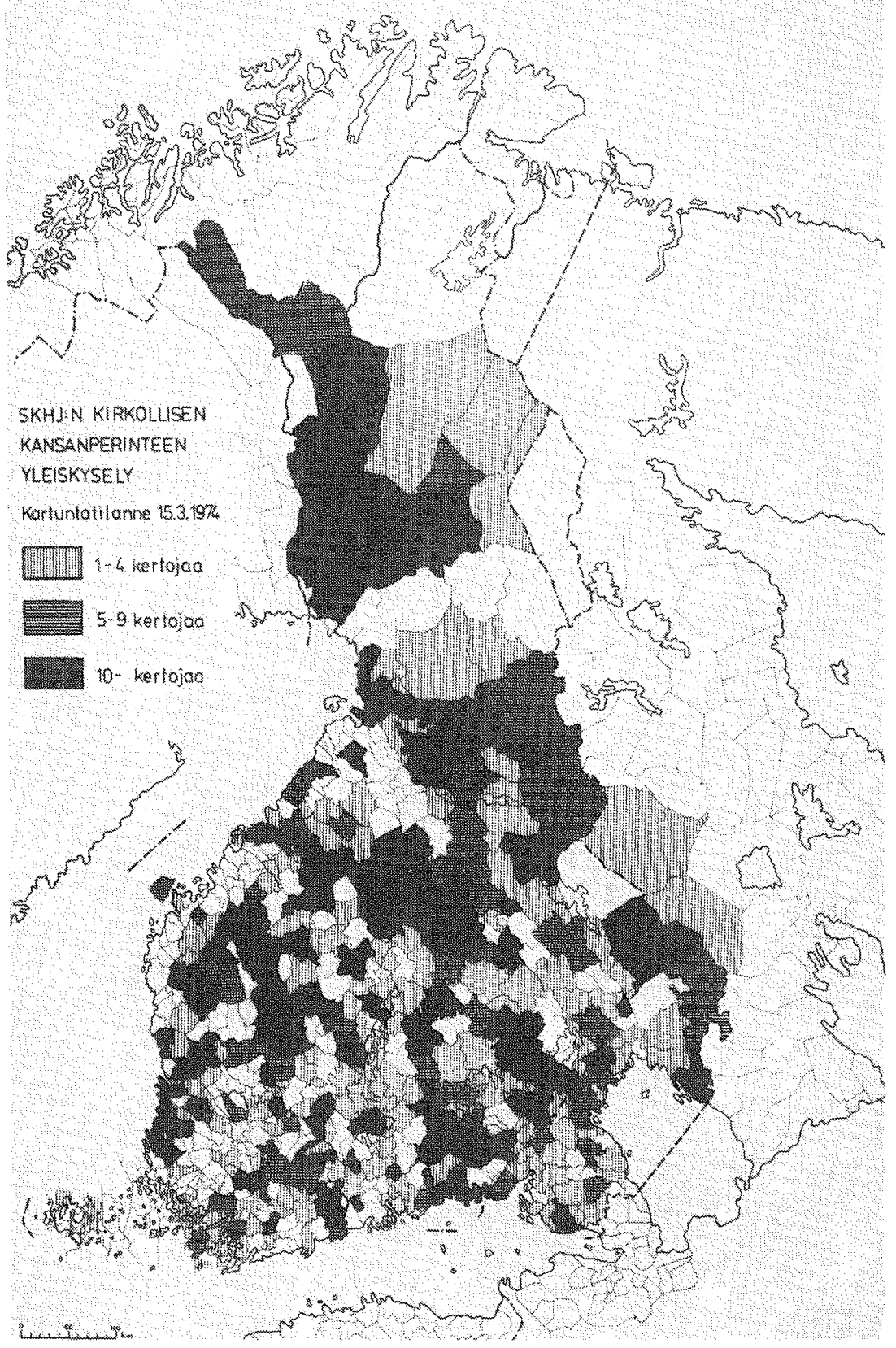

Map 2. Survey of Finnish ecclesiastical tradition. The upper sign indicates $1-4$ informants; the middle on 5-9 informants and the lower one 10 or more informants. 


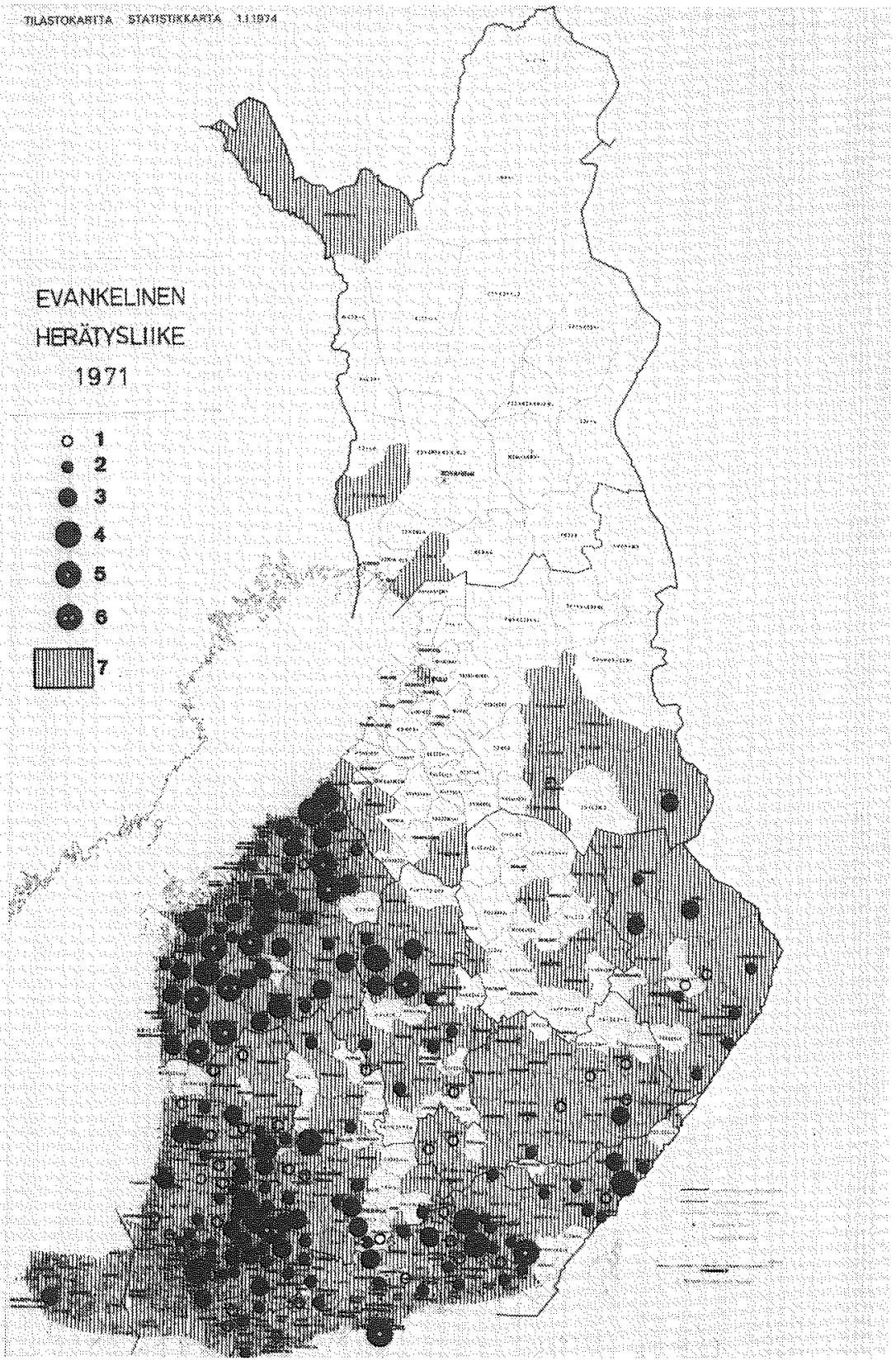

Map. 3. Evangelist movement 1971. Evangialism is the most organised of the Finnish evangelistic movements. The map shows the number of members in the local branches of both Finnish- and Swedish-speaking local organisations: 1. 1-24, 2. 25-74, 3. 75-149, 4. 150-599. 6. 600-999. 7. represents those congregations within which there is evangelic activity. (Uskonnollinen liike, 21.) 
is must be clarified by utilisation of material gathered among the people by means of field work to supplement the information given by the clergy.

\section{The micro and macro levels of Finnish ecology of religion}

The cartographic method has been applied to the study of Finnish revivalist movements from the 1950's onwards. In 1956 W. A. Schmidt presented his conception of Finnish church geography by dividing the country up into seven main areas of religious support: South western Finland with its Kneepraying, the area of Sortavala in Ladoga Karelia with its Renqvistism (the name after the founder of this knee-praying group, Henrik Renqvist), Central Finland with its Revivalistic pietism, Southern Finland with its Evangialism, Häme with its Church Pietism, the Biblicism of the Ostrobotnian lake district, and Northern Finland with its Lestadianism. In his article Schmidt also attempted to explain the areas thus outlined making use of social, economic, and ethnological factors. He regarded the following as the most significant background factors: the spread of industrialisation, internal migration, the cultural boundary between Eastern and Western Finland, and the dialect boundary between Eastern and Western Finland. ${ }^{18}$ Schmidt's hypotheses have subsequently been revised by Ari Haavio, Lauri Koskenniemi and Jouko Sihvo. ${ }^{19}$

The cartography of the revivalist movements easily pales into the presentation of incorrect generalisations if the basis of the mapping is only information concerning the presence or absence of a religious movement in the congregation report. In studying the religious geography of revivalist movements attention must be focused not only on the presence of a movement, but also on the density of its support, the regularity of its activity, and on its intensity and tendency to spread. In this respect it is evident that, for example, a map of evangelistic movements giving the impression of being static begins to assume some color with each movement showing a core area in which the degree of organisation is high, the activities and behavior of the members subject to a substantial degree of social control, and the influence of the central governing body strong. At the edge of the core areas there are peripheries in which activities are less organised, and the behavior and views of the supporters and members of the movement demonstrate a larger degree of variation than is the case in the core area. Some areas, often

${ }^{18}$ Cf. Schmidt 1952, $1 \mathrm{ff}$; and 1956, $1 \mathrm{ff}$; Pentikäinen 1975, $77 \mathrm{ff}$.

19 Cf. Haavio 1963, 1 ff; Koskenniemi, 1 ff; Sihvo, 1 ff. 
found at the outskirts of large cities, as is the case with the South western Knee-prayers, turn out to be archaic relic areas, others are isolates. On the other hand it is possible to demonstrate some areas to be more sensitive than others both as to religion and to social and cultural changes in general (innovation areas).$^{20}$ It is clear that thorough familiarity with the problematics of geography of religion would presuppose empirical investigations, interviews, and detailed study of the archives of religious movements in addition to the reports given by the parish priests in studying the revivalist movements.

A religio-geographical standpoint requires a cultural-ecological approach to supplement it. Julian Steward, the classical writer on cultural ecology regards a study of those processes by means of which a community adapts itself to its environment as its most important task. The central problem is one of determining whether the adaptations in question cause any social or developmental changes. Analysis of adaptation presupposes study of previous changes, of the reciprocity existing between communities and social institutions, as well as consideration of the bilateral relationship holding between these communities and their natural environment. ${ }^{21}$ The religioecological aspect does not only mean clarification of the relationship between the natural environment and religiosity. The environment is regarded from a wider perspective than that of a habitat biosphere; it is seen as having cultural values and a communications system comprising a symbolic frame of reference between the community and the individual. In cultural ecology we are thus concerned with relating three different groups of components: the history of the environment of the individual, and of the community (tradition or culture). In clarifying the relation holding between tradition and the cultural environment it has been pointed out that tradition often undergoes changes when entering a new cultural environment. The Swedish folklorist von Sydow termed these phenomena 'oicotypes'. ${ }^{22}$ On the other hand a culture might also reject some of the innovation theoretically within its reach. In the acquisition of tradition we are thus faced with a process of social selection, crucially influenced by the requirements of the community as regulated by factors such as the environment. ${ }^{23}$

\footnotetext{
${ }^{20}$ Cf. Pentikäinen 1968, $105 \mathrm{ff}$.

${ }^{21}$ Cf. Steward, 337 ff; Honko 1972, 95 ff.

${ }^{22}$ Cf. Sydow, $44 \mathrm{ff}$.

${ }^{23}$ Cf. Honko 1973, $30 \mathrm{ff}$.
} 
A cultural boundary is formed in a locality where the barrier of selection has been high. Because social changes, such as the influence of industrialisation, regulate cultural selection, the ecological aspects in benefited by diachronic investigation. For this reason efforts should be made to distinguish between the selectional barriers and the cultural boundaries prevailing in different periods when studying the history of tradition.

In the study of religion the ecological aspect has been understood as referring to guiding religio-phenomenological investigation in a new direction characterised by the quantification of empirical data. ${ }^{24}$ On the macrolevel the problems may even be concerned with the deep structures of religions and cultures. For example: is the shamanism generally encountered in arctic areas a form of religion dependent upon the environmental and cultural environment, or can its spread be explained as a result of contact (acculturation)? We are also moving on the macro-level when attempting to explain the cultural and environmental factors exerting an influence on the spread of Finnish religious movements. ${ }^{25}$ One might ask whether the individualism of Revivalism by 'taking the low road' and opposing organisation has any relationship to the cultural environment in which the movement originated, i.e. Savo dispersed population patterns. Might the strict organisational patterns of Evangialism be explainable in that the core area of the movement-the south western village communities was densely populated and typified by a high degree of organisation on the village level? Has Lestadianism undergone a change after having shifted its central area of influence from arctic Lappland to Ostrobotnian agricultural villages and establishing its headquarters at the city of Oulu?

There is al so a micro-level of religious ecological investigation which may concern the contact of religious movements in some area. Typical examples would be the dynamic area of encounter between Evangialism, Revivalism, and Lestadianism in Central Ostrobotnia, Southern Ostrobotnia with its Revivalism and Evangialism, and Satakunta with its Knee-praying and Evangialism. A religio-ecological study assumes the aspect of depth research in those cases in which the object of research is the village, the family, or the individual. In studies of communities the mappings of reciprocity between social groups and the typological studies of bearers

\footnotetext{
${ }^{24}$ Cf. Hultkrantz, 103 ff; Honko 1972, 102 f.

${ }^{25} \mathrm{Cf}$. Sarmela, $76 \mathrm{ff}$.
} 


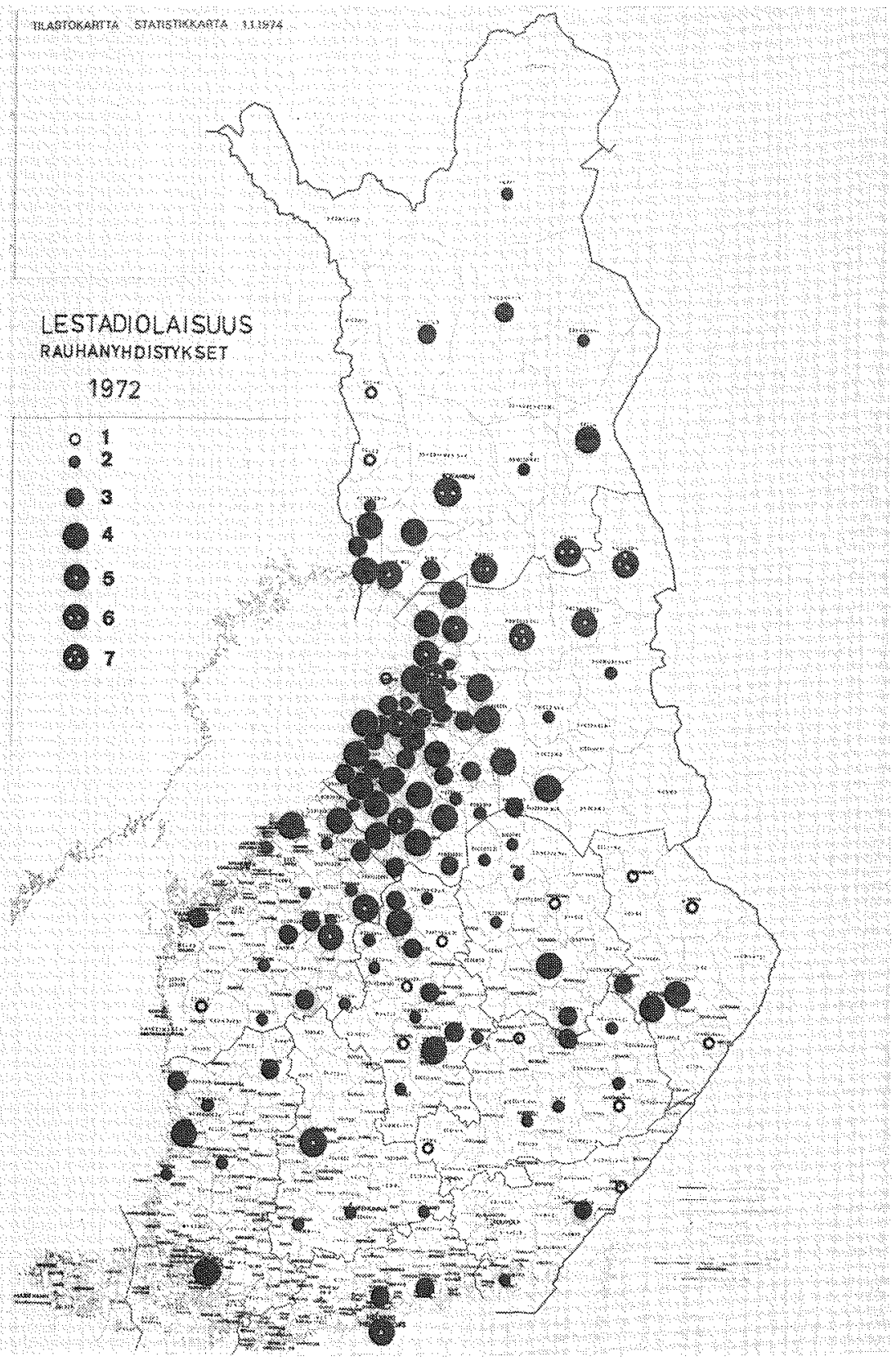

Map. 4. Conservative Lestadianism. Local congregations (Peace Societes). 1972. This depicts the density of membership of the contemporary mainstream of Lestadianism, the so-called Conservatives. The symbols indicate the number of member Lestadianists of the Peace Society in the congregation: 1. 1-24, 2. 25-74, 3. 75-149, 4. 150-299, 5. 300-599, 6. 600-999, 7. over 1000. (Uskonnollinen liike, 31.) 


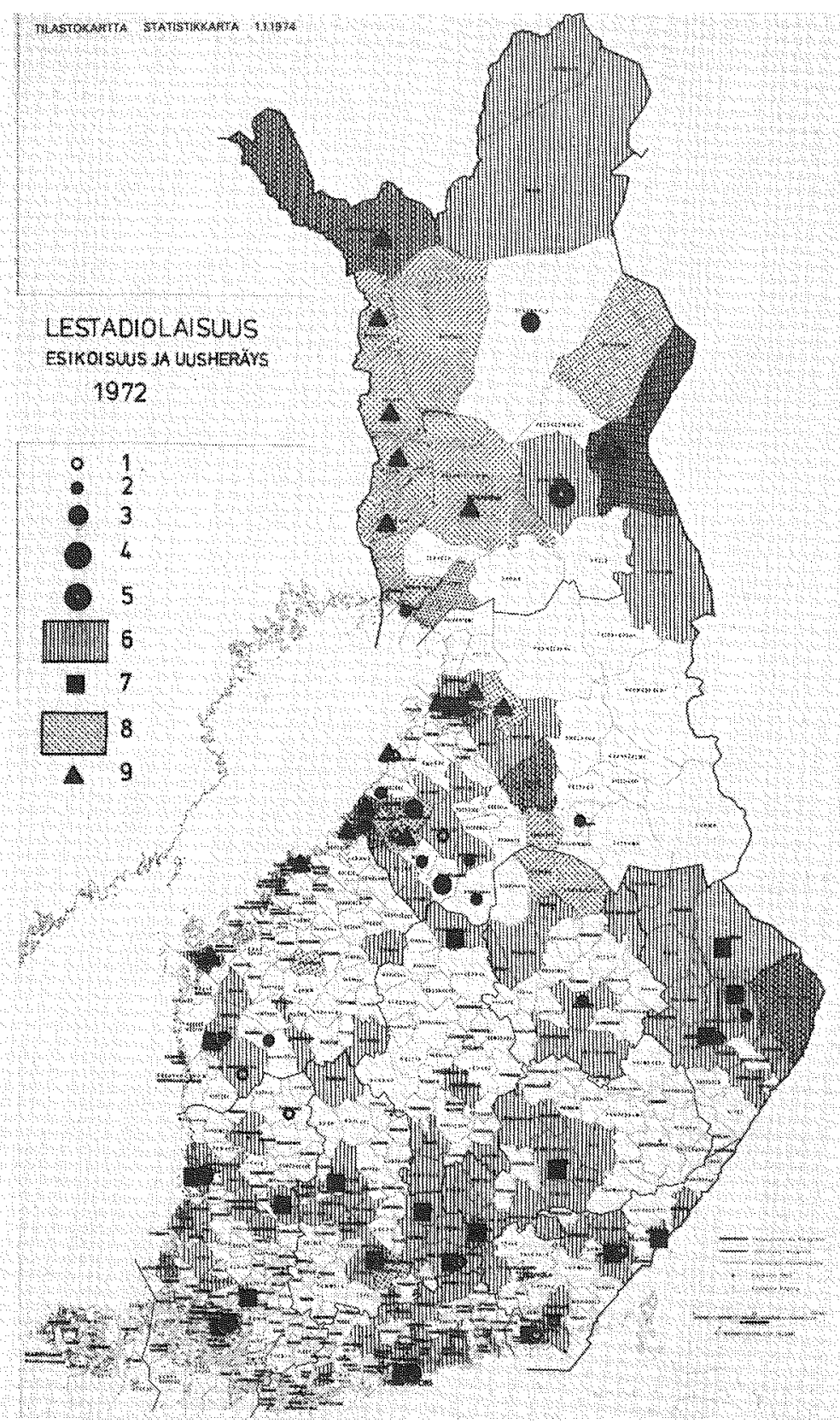

Map. 5. Lestadianism. The First Born and the Neo-Revivalists. 1972. The degree of organisation in the splinter groups which came into being as a result of the splits in the Lestadianist evangelical movement is of a lesser degree than that found in conservative Lestadianism. Ad- 
of tradition produced provide the possibility of investigating the adaptation of tradition on the levels of the individual, the small group, the community (e.g. village), and the geographical area.

In the study project mentioned above we have from 1973 onwards directed investigation in the religio-ecologic direction on both the micro and the macro levels. The goal has been a mapping of the Finnish religious communities indicating their ecological and geographical characteristics which would use as primary data the congregation reports drawn up for church meetings, the private archives of the religious movements, and the material collected first hand in the form of interviews and field observations. Since one of its parallel purposes is to focus attention on the social, cultural, and religious change which took place in the twentie th century, a cross-section of material representing social, cultural, and church events has been collected using automatic data processing methods for the years 1900, 1912, $1919,1927,1936,1941,1946,1951,1961,1971$. The nationwide matrix thus obtained contains 107 parameters and provides a basis for the clarification of religious and ecological questions covering the entire country. ${ }^{26}$

In addition to the data concerning the entire country, religio-ecological investigation has now been concentrated on twelve target areas selected on the basis of a strategic sampling. The target areas were selected primarily on the basis of three variables: $(a)$ religio-geographical, $(b)$ socio-political, and $(c)$ ethnological (map 1). The target areas are generally units consisting of several cities or communes, so that it is possible to carry out comparison between urban and rural communities within the same target area. In the group are included dynamic points of contact (Central Ostrobotnia, Southern Ostrobotnia, South west Finland, Northern Karelia), and areas influenced by one particularly strong movement (Northern Savo, North east Ostrobotnia, the Tornio River Valley, Lappland). Included are also inno-

${ }^{26}$ Cf. Suolinna, Kirsti $1975 a, 28 \mathrm{ff}$; and $1975 b, 57 \mathrm{ff}$.

ditionally, the areas in which these groups exert a direct influence are more dispersed. It is difficult to determine the strength of support as to individual area. Three groups are represented on the map. Explanation of symbols: Members of the Central Associations of Lestadian Missionary Associations: (neo-revivalists) 1. 1-24, 2. 24-74, 3. 75-149, 4. 150-299, 5. 300-599. Members of the Old Lestadianist Christian Association (first Born): 6 support, 7. prayer room. Word of Peace (Rauhan Sana) (Small first Born), 8. Associations cared for by missionaries in the area, 9. local association. (Uskonnollinen liike, 35.) 
vation areas in which new religious groupings seem to become easily established (Jyväskylä, Forssa, Kouvola and its surroundings). The economic and social structure as well as the geographical distribution of different political affiliations have been taken into consideration as socio-political factors in selecting targets areas. From the ethno-ecological standpoint the division of the country into different types of natural and cultural environments has also been taken into consideration; Lappland and the coastal region are taken as representatives of western Finnish cultural areas; Savo and Northern Karelia as representatives of eastern Finnish cultural areas. ${ }^{27}$

The purpose is to draw up regional spot investigations for each target area capable of clarifying religious encounter on a micro basis. ${ }^{2}$ In addition to these, investigations are being carried out on the village level, typical of which is Leena Räisänen's study of Töllinperä in Nivala. In this work religious contact is investigated on the village level. Leena Räisänen's licenciate thesis "Religion as a divisive factor in communities, a case analysis from the village of Töllinperä in Nivala" (1974), is based on extensive interview and first-hand investigation carried out by three researchers in the village, in addition to the writer herself. Leena Räisänen demonstrated that there are important degrees of difference in religious convergence. The inhabitants of the village are not only Revivalists or Lestadianists, but there are also those identifying themselves in different manners with both of the movements as well as those who are either indifferent or opposed to both. Membership in a religious organisation regulates contacts and activities in the village in many different ways, in addition to influencing interpersonal relationships on the social and economic levels as well as on the religious level..$^{29}$ Those studies dealing with the personality or the individual are also concerned with the micro-level.

\section{In-depth studies of religious leaders and the common people}

In studying the dynamics of religious movements it has been possible to make the significant observation that within the same movement there might appear views and modes of behavior demonstrating a considerable

\footnotetext{
${ }^{27}$ Cf. Talve, $185 \mathrm{ff}$; Sarmela, $76 \mathrm{ff}$.

${ }^{28}$ Cf. Pentikäinen 1975,77 ff.

${ }^{29}$ Cf. Räisänen, 1 ff.
} 
degree of difference. To put it approximately, one must differentiate between the levels of religious leaders exerting social control, religious diffusionists, and that of the people belonging to a movement. In the historical study of religious movements the emphasis has naturally been up until now on religious leaders. This is natural since there is more literature and archive material concerning them; additionally investigating them as social diffusionists might otherwise seem more significant than studying the individual supporting members of a movement. Because a change taking place within a religious movement, either as to dogma or as concerns the social make-up of its membership, might be the result of changes in world view taking place on the level of the common people, neglect of this level in historical investigation could turn out to be an extremely fateful error. Sociologists of religion have been interested in clarifying the opinions of the common people, but they have not focused much attention on individual differences of opinion. On the other hand, this diffusion has been studied as an example of reciprocity in which individuals, the community that they form in both time and space, and the symbolic biosphere formed by the culture all participate.

A new feature in the study of religious leaders has been the fact that up until now more use has begun to be made of data concerning tradition to supplement the more usual archive and literary sources. Thus, living religious leaders, such as itinerant preachers, have been the objects of study in which both direct observation and life-historical interviews have been used in fieldwork for the purpose of clarifying the developmental phases of the individual's life, his processes of enculturation and socialisation, the development of his personality and world view, as well as the changes which took place within this. Religious diffusion is no more studied in accordance with what the individual reveals about himself, but rather as a phenomenon which can be observed both sociologically and anthropologically. Thus Päivikki Suojanen has studied two Knee-praying layman preachers, Väinö Aerila and Otto Salonen, as religious leaders with particular attention focused on the speech event of the praying congregations, the sermon situation. This is viewed from the standpoint of both speaker and listener. ${ }^{30}$ Tuula Jäntti has clarified the life history of the Lestadian minister Antti Koskela as well his sacral and secular roles in the Ostrobotnian village com-

${ }^{30} \mathrm{Cf}$. Suojanen, $1 \mathrm{ff}$. 
munity. ${ }^{31}$ The object of Leo Väyrynen's investigation was the conversion of the Ostrobotnian Juho Rankinen to Lestadianism. ${ }^{32}$ The purpose was to clarify the manner in which a converted person re-analyses his world in a dramatic manner and thus acquires a new symbolic frame of reference. The study makes use of thorough analysis of material obtained both from archives and interviews. Religious diffusion seems to be a multi-dimensional situation of reciprocity clarification which has not only the bearer of the doctrine himself but also the people living in the social environment, no matter whether they support him, oppose him, or are indifferent to him, in the role of key informants.

My study, 'Marina Takalo's Religion' (1971) written after ten years of interview and first hand observation, gives indications of how a change in world view can be investigated on the level of the people. Marina Takalo was an Orthodox immigrant born in White Sea Karelia in 1890. She moved to Finland in 1922 and ultimately wound up changing her environment some thirty times until her death in 1970 . She was a conservative Orthodox believer as to religion belonging in her youth to an old Believer sect. Her world view cannot, however, be said to correspond to that usually associated with the Orthodox religion, nor does it respond to the collective tradition of White Sea Karelia. Instead, it is an idiosynchratic system dependent upon an individual personality and its development as well as on changes in the symbolic frame of reference. A religio-anthropological investigation of the illiterate Takalo's faith illuminates not only different forms of the White Sea Orthodox faith, but also the manner in which a believer guided by tradition selects views and modes of behavior by methods of oral tradition. In a manner differing from what would be expected in the case of a person guided by tradition one does not see Marina Takalo's world view as a static entity; rather it is one which seems to change so as to emphasise in different manners the environment, community, stimuli, and needs regulating an individual's personality during the different phases of his life. An individual's religious repertoire changes as does his personality. The amount of material stored in a person's memory is extensive when viewed as an aggregate; nevertheless only part of it belongs to a frame of reference regulating activity and behavior at any one time. When, as in the case of Marina

${ }^{31}$ Cf. Jäntti, Tuula, 200ff, for more exact information.

${ }^{32}$ Cf. Väyrynen, $169 \mathrm{ff}$, for more exact information. 
Takalo, one also'studies the manner in which other individuals and personalities exert influence within religious movements one would undoubtedly obtain information useful for the clarification of a portrait of Finnish religious life on a more empirical basis than that which is now available. ${ }^{33}$

\section{The acculturation of religious minorities}

Religious minorities, of which there are only 19 registered, exert a dispersing influence on the homogeneity of the Finnish religious map. Of these, only the Orthodox Karelian culture can be characterised as regional culture. The acculturation into the mainstream of Finnish culture was greatly accelerated by the evacuation of the Karelians to different parts of Finland after the Second World War. A total of 56, 816 persons belonged to Orthodox congregations in $1970 .^{35}$

In all areas the other religious minorities are in a clearly minority posi-

\begin{tabular}{lrrr}
\hline Religious Groupings in & $\begin{array}{l}\text { Number of } \\
\text { parishes }\end{array}$ & $\begin{array}{l}\text { Number of } \\
\text { members }\end{array}$ & $\begin{array}{l}\text { In } \% \text { of } \\
\text { total population } \\
(4598336)\end{array}$ \\
\hline Finland 1970 & 595 & 4244425 & 923.03 \\
Lutheran National Church & 25 & 56816 & 12.36 \\
The Greek Orthodox Church in Finland & 13 & 1148 & 0.25 \\
Finnish free Evang.-Lutheran congregations & 1 & 2153 & 0.47 \\
Swedish Lutheran Church & 2 & 1160 & 0.25 \\
Greek Catholic (private) Church & 5 & 2524 & 0.55 \\
Roman Catholic Church in Finland & 1 & 69 & 0.02 \\
Anglican Church in Finland & 3 & 4090 & 0.89 \\
Adventists & 6 & 1708 & 0.37 \\
Baptists & 25 & 1694 & 0.37 \\
Methodists & 20 & 7447 & 1.62 \\
Free Church in Finland & & - & - \\
Christian Community in Finland & 16 & 8977 & 1.95 \\
Jehovah's Witnesses & 3 & 1217 & 0.26 \\
Jewish Community & 23 & 1894 & 0.41 \\
Jesus Christ Church & 2 & 23 & 0.18 \\
Islamic Community & 2 & 114 & 0.02 \\
Free Catholic Church & 1 & - & - \\
Friends of Truth & 4 & 72 & 0.02 \\
Bahái Community & & & \\
\hline
\end{tabular}

33 Cf. Pentikäinen 1971, 1 ff.

${ }^{34}$ Cf. Vuosikirja 1971, 4; and Tilasto 1973, 404.

${ }^{35}$ Cf. Tilasto 1973, 404. 
tion, having the status of sub-cultures, although it is true that the Pentacostalists and Jehovah's witnesses do carry on nationwide missionary work in Finland. ${ }^{36}$ Encountered much less frequently are supporters of the Free Finnish Church and the Adventist Church. ${ }^{37}$ There is an old area of Baptist support in Finnish-Swedish Ostrobotnia as well as in the environs of Jyväskylä. ${ }^{38}$ The other religious minorities appear to have become ensconced only in the largest Finnish cities. In regards to the provincial cities, the most receptive centers of religious innovation seem to be Jyväskylä, Kuopio, Mikkeli, Savonlinna, Joensuu, and Kouvola in the light of available statistics. ${ }^{39}$ What can the susceptibility of these areas to new stimuli be attributed to? Could it be explained using target analysis based on religioanthropological and sociological material?

In investigating Finnish religious minorities a clear difference can be observed in the types of cultural contact which the ethniconational and religious factors are bound together by. The Jewish and Islamic congregations, the Swedish Olaus Petri congregation, as well as the Anglican and Roman Catholic Church in Finland are representative of this group. The members of these religious communities are primarily immigrants who have come to Finland. In addition to retaining their values and concepts of religion, they also attempt to preserve their distinct culture. They do not attempt to proselytize, nor do they make efforts to expand. An ethnic-religious minority has as its main task the preservation of its membership. Mixed marriages are regarded as a threat to the continuity of the community. Some communities, such as the Jewish and Islam congregations, actually discourage converts. An interesting question which arises when studying these ethnic-religious minorities is that of enculturation and socialisation. How does the minority transfer cultural tradition to the new individuals born within it? How are the norms learned? How does the community satisfy those conflicts in values arising when the ethical views it represents come into contact with those of the mainstream culture? In order to clarify the enculturation and socialisation problems of religious minorities there is a project underway within which questions of comparative religion and pedagogics are united.

\footnotetext{
${ }^{36}$ Cf. Haavio $1965,150 \mathrm{ff}, 162 \mathrm{ff}$.

${ }^{37}$ Cf. ib., 123 ff, 155 ff.

${ }^{38} \mathrm{Cf}$. ib., $143 \mathrm{f}$.

${ }^{39}$ Cf. Väestölaskenta, 357, 390, 393, 420, 441, 466.

8-752446 H. Biezais
} 


\section{The rise of new religious splinter groups and contracultures}

In 1973 the research project dealing with religious communities was extend to include urban communities. The reason for this is that it became evident that a cartographic, religio-geographic, or ecological methodology does not provide very much information in regard to the dynamics of new religious movements. Instead, it seemed justified to seek supporters of religious movements in certain social groups of urban centers. These new religions seemed to be guided internationally, they are representative of imported innovation, and are linked with the super-national rise of youth culture and the protest movements spawned within it, such as the hippies, the beatniks, the Jesus-movement, the neo-Hinduists, guru and yoga groups.

Helsinki and Turku were selected as the objects of this religio-anthropologic and sociologic project, the reason for this selection being that both investigations can be partially directed from university departments of comparative religion as graduate thesis. Additionally, there is an investigation concerning Helsinki which has as its object the religious life of that city. It is based on field work carried out in 1964 with which fieldwork carried out ten years later may be compared to. ${ }^{40}$

Additionally, Helsinki and Turku are the two Finnish cities in which international innovations first seem to become established. Helsinki, with its population of half a million is the only real metropolis in Finland; Turku, on the other hand, has traditionally played the role of gateway to Scandinavia with the first signs of innovation acquired from Scandinavia often being noticed in this city. The main methods of fieldwork are observation and interviews. This is natural, since the new religious communities seem to operate in small groups both in Helsinki and in Turku. The movements are additionally of such recent origin that there is not much documentary material concerning them in existence. It is difficult to obtain exact quantitative information concerning the new religions, since membership in these movements does not usually entail a change in religious affiliation. Many of the new movements are of such a nature that they do not demonstrate conscious efforts to be classified as religions in the traditional sence. Instead they come under the classification of yoga or meditative societies, with some even being classified as scientific associations.

${ }^{40}$ Cf. Koskelainen 1966, 1 ff. 
In November 1974 a survey was carried out by the Institute of Comparative Religion concerning all the religious activity available in the city of Helsinki. A comparison with the investigation carried out ten years previously demonstrates the number of rel igious movements to have undergone a considerable increase. The religio-sociological study carried out in 1964 encompassed some thirty religious societies functioning within Helsinki in addition to churches and associations inside them. The number of movements studied some ten years later was almost 100 . Of these almost 100 societies, 62 announced their activity publicly in the columns of the Helsinki newspapers. Of those announcing, 10 were societies belonging to the revivalist movement of the Evangelical Lutheran Church. Eleven represented missionary or evangelical movements within the church. Of the religious groups included in the official register of religious associations ten announced their activities, 9 Pentacostalist congregations advertised in the classified section of the newspapers as did 5 syncretic or anthroposophic societies, 3 meditation or yoga groups, in addition to 4 Christian political groups. It is interesting to note that those registered congregations whose membership consists of religious and ethnic minorities did not make use of public media during that period. Additional note should be made of the fact that many of the oriental, guru, yoga, and meditation societies disseminated their information during the period of the investigation primarily by underground means or by word of mouth rather than make use of mass communications media. A study of the press furnishes a picture of the religious activity available in Helsinki: according to it some $60 \%$ of the city's religious organisations practice activity proselytising. It is also noteworthy that of the religious communities in Helsinki, some $80 \%$ seem to be neglected from the standpoint of official statistics. Some of the organisations function as associations belonging to the official registry or as societies. Most of them, however, function as free groups. Groups of this nature have also been formed around such clairvoyant figures as Aino Kassinen and John Sundström.

Most of the religious organisations to be found in Helsinki present innovation brought to Finland from elsewhere or innovation adapted from elsewhere. A few groups have begun independently in Helsinki but they are characterised by schismatic factors arising from personal disagreements which ultimately resulted in factioning of the movement. This is the reason for the Finnish theosophical movement being divided into several small 
groups. Even though each unit seems to differ from each group as to dogma, norms, and social structure, I would hesitate to call them religions but would rather use the term 'religious subculture'. Some of the most recent religious communities in Helsinki have a very free aspect, others show a higher degree of organisation. The formation of a religious group usually begins with a small, free group being formed. This consists of a group of disciples meeting under the auspices of some clairvoyant figure. A group originating in this matter might gradually become organised to an increasingly higher degree and develop its own system of belief, cult, and organisation. Formation of a religious organisation usually begins on the basis of the founder's own religious experiences, the myths and legends arising from these which eventually crystallize into doctrines and sometimes assume written form. The cult is centrally connected with experiences in which the myths are realised. When the degree of organisation precedes further a group with free form or an evangelical movement organises itself into a distinct community having its own economy, staff, and set mode of organisation. In studying religious subcultures it is important to discover the mode of their acculturation to a new symbolic frame of reference. No religious group originates in a vacuum, but rather it eventually must adapt itself to the culture of the community. If the cultural barrier is extremely high, the innovation stands a chance of being rejected ${ }^{41}$

The commune movement propagandised by many international organisations, give s the impression of being exceedingly alien to Finnish society and culture. At the same time meditation and yoga societies, such as the Transcendental Meditation led by Maharishi Mahesh Yogi, seem to have spread very satisfactorily to Finland. Many of the religious communities requiring adherents to live in communes have been rejected at the same time, or their spread has been extremely slow.

Hos has a religious movement been adapted as an innovation in a Finnish urban center? Let us take the Divine Light Mission as a recent example. A religio-anthropological study of this community was carried out during its first year in Finland. ${ }^{42}$ The central figure of this movement is Guru Maharaj Ji, born in 1957. His first Finnish supporters received the illumination in Copenhagen in autumn, 1972. This knowledge means experiencing God, and it can be acquired by practicing the four techniques of meditation

${ }^{41}$ Cf. Honko 1973, $30 \mathrm{ff}$.

${ }^{42}$ Cf. Junnonaho, $1 \mathrm{ff}$. 
and opening up completely to receive the mercy of Guru Maharaj Ji. The guru's disciple, termed premies, organise a satsang which is an organisation of truth. In these satsangs the spiritual knowledge attained by the guru is discussed, techniques of meditation are studied, music is prevented, and certain rites are formed. The movement began functioning in Finland in 1973 in Turku. This activity was initiated by two university students who had received the "knowledge" in Copenhagen the previous autumn. In February 1973 activity became established on a firm ground and it was led by a young Argentinian named Pablo. After this, a satsang was arranged in Turku which met every evening and whose activity was publicised in the city as well. In March five members of the circle went to Copenhagen in order to receive the world, in April 1973 the mahatma visited Finland for the first time, but he did not divulge the word to anyone. In June 1973 thirteen adherents from Turku travelled to Copenhagen in order to receive the word. The circle had expanded to such a degree that it founded an ashram in Tur$\mathrm{ku}$, that is to say, an operating unit of its own. In July a public lecture was organised at the university and it was widely publicised. The mahatma did not, however, make an appearance as promised in advance. In August the mahatma made a second visit to Turku and he organised a public lecture in Helsinki as well. In September he made a third visit in connection with which he devulged the word for the first time in this country to nine Finns. In October 1974 the first permanent ashram in Finnland was established in Turku. At the same time a 'Guru Shop' was opened and systematic announcement of the activities of the movement were begun on a bulletin board set aside for this purpose.

As was the case in the entire project when studying this movement as well the investigator concentrated his attention on the questions of why and how the movement came to Finland and what kind of people it appealed to. In this case it was interesting to note that the Divine Light Mission first came to Turku as an innovation brought about through private contacts. Comparative reasearch has demonstrated many contracultures and new religious subcultures to have come to Finland in the manner of the Divine Light Mission. They spread primarily to the big cities and acquired supporters chiefly among youth. The advancement of the movement seems to be intermittently connected with the trips of the leader guru and the investigation carried out of the meetings in Turku clearly demonstrates the decisive degree to which the activity of the Finnish community has been dependent on the 
visits of the mahatma, 'the great soul'. A central feature of the visits has been the transfer of tradition constituting the inititiand; this is not possible without the mahatma. The study of the movement indicates that in Finland its core-group, those regularly participating in its activities, was relatively small, amounting to some ten persons. All those who have received the word and undergone initiation do not necessarily become active members. However, during the period of observation it became evident that the number of members following the satsangs increased from fifteen to thirty-five. Important events at the mission were the visits of the mahatma and the guru, events that also created publicity for the movement in the mass media. After these trips the membership increased with activity gradually petering out to its normal course. Characteristic of the innovation is the fact that activity initially began in Swedish or in English, the language of the first converts. The main language became Finnish only the following spring. The increase in public activity also awakened opposition, although this did not come from the official organisations of the churches. The guru society competed with the Jesus people of Turku who disturbed the meetings of the organisation by asking controversial questions at the meetings and defacing the bulletin boards.

Attainment of a permanent ashram signified a decisive forward step in the organisation of a community. The accessories needed for the establishment of an ashram, as well as the ritual behavior carried out within it, were all in strict accordance with the guidelines received from London. An ashram had a foyer, a satsang-room, a bedroom, an office for the brothers, a bedroom for the sisters, and a smaller room for the visits of the mahatma. The social behavior appropriate for the ashram was regulated by rules forbidding use of narcotics, tabacco, marital relations, of personal property with the exception of clothing. It was thus a commune in many respects reminiscent of those communities formed in America on a religious basis. Research has demonstrated that the ashram served primarily as a religious institution to its adherents, and only secondarily as an organisation for togetherness. In Turku the organisation had a secretary, a treasurer and internal equality. Its mode of operation was in accordance with the Divine Times and the instructions given by the guru and mahatma. In Turku the membership consisted primarily of youth with a mean age of twenty years. Only later did some middle aged women join the community. Almost all were members of the church, although there was one muslim in the group. Almost all were ad- 
ditionally representatives of the higher social classes. They had received the word a month or two after having heard the first satsang. Information concerning the Divine Light Mission turned out to be passed by word of mouth in Turku; the members had heard about the community from some friend or acquaintance with only two having come along after having seen the bulletin. It is also significant to note that the interviewees had either had something to do or at least become acquainted with oriental religions before coming into contact with the Divine Light Mission. This usually took the form of yoga. Almost all criticised the Bible. It is also worth noting that of the interviewees only three were such who had not made use of narcotics before joining the community. Nevertheless, they had stopped using narcotics before joining the community. In studying new religious subcultures it has been possible to demonstrate that many of them strive to achieve support from certain social groups. Their spread is social rather than geographical in nature. This spread takes place primarily among the young and the missionary field might very well be the auditoriums of the universities or schools, or meetings at workers' education institutes. In investigating religious groups the purpose has been to create a typology in which the movements would be studied on a cognitive, affective, conative, social, or cultural level. There seem to be groups emphasising knowledge, feelings, cults, certain sets of norms or cultural entireties among the communities. Rarely are the communities ideal types which would become formed on the basis of some criterion. Each dimension seems to have a polar extremity between which the religious groups can be placed according to the emphasis they accord each distinctive feature.

In studying religious groups the concept of contraculture has demonstrated itself to be of use. The term was suggested by Yinger for depicting such sub-cultures as have a dominant element of conflict and which appear to have a strong influence on the behavior of their participants. ${ }^{43}$ The term sub-culture essentially signifies a conflict in values and norms as regards the prevailing culture. It is thus a question of a social phenomenon which can become evident on the religious as well as on the political level. For example the use of narcotics which in some connections seems to be linked with a cult has been regarded as contracultural behavior. ${ }^{44}$ From the standpoint of comparative religion the question of what the nature of the

${ }^{43}$ Cf. Yinger, 167.

${ }^{44} \mathrm{Cf}$. Watts, $166 \mathrm{ff}$. 
process of change undergone by contracultures when arriving in Finland and entering the culture as examples of innovation is an extremely interesting question.

\section{Bibliography}

\section{A. Unpublished sources}

\section{University of Helsinki}

Arkkila, R., 1971, Suomen evankelinen liike 1920-1929. Theol. lic. thesis in Finnish Church History.

Räisänen, Leena, 1974, Uskonto yhteisöjen jakajana. Phil. lic. thesis in Comparative Religion.

Väestölaskenta, 1970. Taulu 005. Väestö uskontokunnan ja iän mukaan (kunnittain) 31.12. 1970. Tilastokeskus.

\section{University of Turku}

Junnonaho, M., 1974, Divine Light Mission ja sen ensimmäinen vuosi Turussa. - Uskontoantropologinen yhteisötutkimus. M.A. thesis in Comparative Religion.

Suojanen, Päivikki, 1974, Spontaani saarna: esitystilanne ja rakenne. Phil. lic. thesis in Comparative Religion.

\section{B. Published sources}

HSLT Helsingin yliopiston sosiologian laitoksen tutkimuksia. Helsinki.

T Temenos. Turku.

UL Uskonnollinen liike. Pieksämäki.

Allardt, E., 1974, Uskontososiologia. Uskonto ja yhteisö. Helsinki.

Boreman, P., 1953, Laestadianismen. Stockholm.

Brännström, O., 1962, Om laestadianska själavårdstraditionen i Sverige under 1800-talet. Uppsala.

Castren, K., 1932, Kiveliön suuri herättäjä. Helsinki.

Haavio, A., 1963, Evankelinen liike herätysliikkeenä. Forssa.

- 1965, Suomen uskonnolliset liikkeet. Porvoo.

Honko, L., 1972, Perinne-ekologiaa - miten ja miksi? Sananjalka 14.

- 1973, Tradition Barriers and Adaptation of Tradition. Ethnologia Scandinavica.

Huhtala, H., 1971, Suomen varhaispietistien ja rukoilevaisten sanankäytöstä. Diss. Suomalaisen Teologisen Kirjallisuusseuran julk. 87. Vammala.

Hultkrantz, A., 1966, An Ecological Approach to Religion. Ethnos.

Juva, M., 1962, Protestiliikkeet Suomen kirkkohistoriassa. Teologinen Aikakauskirja 4.

Jäntti, Tuula, 1975, Saarnaajan roolit ja puhetapahtuma. $U L$.

Kares, O., $1941 \mathrm{ff}$., Heränneen kansan vaellus $1 \mathrm{ff}$. Porvoo.

Kortekangas, P., 1965, Kirkko ja uskonnollinen elämä teollistuvassa yhteiskunnassa. Porvoo. 
Koskelainen, O., 1966, Uskonnosta ja uskonnollisuudesta Helsingissä. HSL T 61.

- 1968, Religiosity in Helsinki. $T 3$.

Koskenniemi, L., 1967, Suomen evankelinen liike 1870-1895. Helsinki.

Nyman, H., 1949, Den bidande tron hos Paavo Ruotsalainen. Diss. Lutherska Litteraturstiftelsens Svenska Publikationer 4. Helsingfors.

Ojaluoto, Elli, 1974, Selvitys Suomen Akatemian rahoittamista tieteidenvälisistä tutkimuksista 1962-1972. Helsinki.

Pentikäinen, J., 1968, The Nordic Dead-Child Tradition. Diss. Finnish Folklore Communications 202. Helsinki.

- 1971. Marina Takalon uskonto. Forssa.

Pentikäinen, S., 1975, Herätysliikkeiden levinneisyyden tutkimus. $U L$.

Rosendal, M., $1902 \mathrm{ff}$., Suomen herännäisyyden historia XIX: llä vuosisadalla $1 \mathrm{f}$. Oulu.

Ruuth, M., 1922, Abraham Achrenius. Porvoo.

Salonen, I., 1930 f., Henrik Renqvist $1 \mathrm{f}$. Helsinki.

Sarmela, M., 1974, Folklore, Ecology and Superstructures. Finnish Folkloristics 2. Studia Fennica 18 . Helsinki.

Schmidt, W., 1948, Fredrik Gabriel Hedberg. Helsingfors.

- 1952, Det svenska Finlands religiösa geografi. Helsingfors.

- 1956, Huvuddragen av Finlands kyrkliga geografi. Acta Academiae Aboensis. Humaniora 22,3. Åbo.

Seppänen, P., 1966, Religious Solidarity as a Function of Social Structure and Socialization. 2.

Sihvo, J., 1973, Laajenevat herätysliikkeet ja niiden leviämisolosuhteet. Kirkon tutkimuslaitos B 15. Tampere.

Sivertsen, Dagmar, 1955, Laestadianismen $i$ Norge. Oslo.

Steward, J., 1968, Cultural ecology. International Encyclopedia of the Social Sciences 4.

Suolinna, Kirsti, 1969 a, Yhteiskunnan ja uskonnollisten liikkeitten suhteista. HSLT 119.

- $1969 b$, Suomen herätysliikkeet sosiaalisina liikkeinä. Sosiologia 6,2.

- 1971, Den laestadianska väckelserörelsen i Tornedalen. Studier kring gränsen i Tornedalen. Nordiske betænkninger 7. Stockholm.

- $1975 a$, Herätysliikkeet sosiaalisina liikkeinä. $U L$.

- $1975 b$, Yhteiskuntarakenne ja uskonnollinen liike. $U L$.

Vuosikirja, 1971, Suomen tilastollinen vuosikirja. (Statistical Yearbook of Finland.) Uusi sarja 66 (1970). Helsinki.

Tilasto, 1973, Suomen virallinen tilasto VI C: 104. Väestölaskenta 1970, 1. [Official Statistics of Finland, VI: 104. Population, census 1970.] Helsinki.

Sydow, C., 1948, Selected Papers on Folklore. Copenhagen.

Takala, L., 1929 ff., Evankelisen liikkeen historia 1 ff. Diss. Helsinki.

Talve, I., 1972, Suomen kulttuurirajoista ja -alueista. Suomalaisen tiedeakatemian esitelmät ja pöytäkirjat 1971. Helsinki.

Tarvainen, O., 1944, Paavo Ruotsalainen luterilaisen kristillisyyden edustajana. LutherAgricola-Seuran julkaisuja 6 A. Helsinki.

- 1967, Paavo Ruotsalaisen opinkäsitys. Lapua.

Tiililä, O., 1944, Suomalainen kristillisyys Wilhelmi Malmivaaran edustamana. Porvoo.

- 1947, Kaste ja usko. Helsinki.

- 1961, Rukoilevaisten kirjoja. Suomalaisen kirjallisuuden seura 270. Helsinki.

- 1964, Suomalaista kokemuskristillisyyttä. Porvoo-Helsinki.

- 1966, Rukoilevaisten kertomaa. Länsi-Suomen herännäisyyden edustajia 1900-luvulla. Helsinki. 
Watts, A., 1971, The Psychedelic Experience. Beverly Hills.

Väyrynen, L., 1975, Uskonnollinen kääntyminen. UL.

Yinger, M., 1970, The Scientific Study of Religion. New York.

Zidbäck, A., 1937, Lars Levi Laestadiuksen kristillisyyden näkemys. Turku.

- 1941, Pohjolan suurin maallikkosaarnaaja Juhani Raattamaa. Helsinki. 